\title{
Molecular Insights into Ternary Surface Complexation of Arsenite and Cadmium on $\mathrm{TiO}_{2}$
}

Shan $\mathrm{Hu},{ }^{\dagger}$ Li Yan, ${ }^{\dagger}$ Tingshan Chan, ${ }^{*},+$ and Chuanyong Jing ${ }^{*}{ }^{\dagger}$

${ }^{\dagger}$ State Key Laboratory of Environmental Chemistry and Ecotoxicology, Research Center for Eco-Environmental Sciences, Chinese Academy of Sciences, Beijing 100085, People's Republic of China

${ }^{\ddagger}$ National Synchrotron Radiation Research Center, 101 Hsin-Ann Road, Hsinchu Science Park, Hsinchu 30076, Taiwan

Supporting Information

ABSTRACT: Insights from molecular-level mechanisms of arsenite $[\mathrm{As}(\mathrm{III})]$ and cadmium $(\mathrm{Cd})$ co-adsorption on $\mathrm{TiO}_{2}$ can further our understanding of their synergistic removal in industrial wastewaters. The motivation for our study is to explore the interfacial interactions of neutrally charged As(III) and cationic $\mathrm{Cd}^{2+}$ on nanocrystalline $\mathrm{TiO}_{2}$ using multiple complementary techniques. The results of adsorption edge, $\zeta$ potential, and surface complexation modeling suggest that coexistence of $\mathrm{As}(\mathrm{III})$ and $\mathrm{Cd}^{2+}$ enhanced their synergistic adsorption on $\mathrm{TiO}_{2}$ and, consequently, resulted in the formation of a ternary surface complex. This ternary surface complex, in turn, inhibited the metal release into the aqueous phase and, therefore, facilitated the immobilization of the heavy metals.

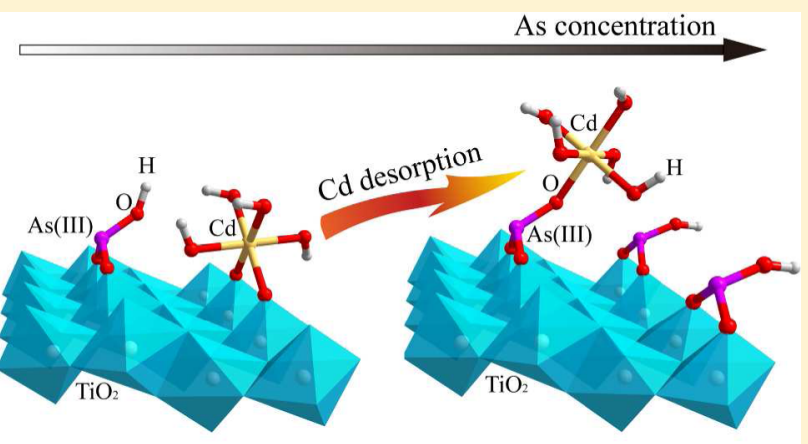

Adsorption

Ternary surface complex

Our in situ flow-cell attentuated total reflectance Fourier transform infrared (ATR-FTIR) spectroscopy and extended X-ray absorption fine structure (EXAFS) spectroscopy evidence showed that, regardless of the order of contact, As(III) was preferentially adsorbed on $\mathrm{TiO}_{2}$ rather than $\mathrm{Cd}$. In agreement with our spectroscopic analysis, quantum chemistry calculations also illustrated that the $\mathrm{Cd}-\mathrm{As}(\mathrm{III})-\mathrm{TiO}_{2}$ ternary surface complex should be formed with the adsorbed As(III) as the bridging molecule. At high As(III) concentrations, the formation of the $\mathrm{Cd}-\mathrm{As}(\mathrm{III})-\mathrm{TiO}_{2}$ complex is responsible for the Cd removal. The simultaneous removal mechanisms will further our understanding of the removal of multiple pollutants in industrial wastewaters.

\section{INTRODUCTION}

Coexistence of arsenic (As) and cadmium (Cd) with extremely high concentrations in mining and smelting wastewaters presents a major challenge to the environment. ${ }^{1,2}$ Arsenate $[\mathrm{As}(\mathrm{V})]$ is the primary As species in oxic environments, whereas under reducing conditions and especially in industrial wastewaters, the more toxic and mobile arsenite $[\mathrm{As}(\mathrm{III})]$ is predominant. $^{3-5}$ Simultaneous adsorptive removal of As(III) and $\mathrm{Cd}$ can be successfully achieved using regenerable $\mathrm{TiO}_{2}{ }^{6}$ However, the molecular-level interactions between cationic $\mathrm{Cd}$ and neutrally charged $\mathrm{As}(\mathrm{III})$ on the $\mathrm{TiO}_{2}$ surface are poorly understood.

The rapid increase in industrial mineral exploration and extraction over the past 2 decades $^{7}$ has motivated extensive studies on the interactions of metals and oxyanions on solids. $^{8-10}$ The synergistic uptake of cationic metals and anionic ligands on metal oxide surfaces is generally attributed to the electrostatic effect, formation of ternary surface complexes, and surface and bulk precipitation, as evidenced by spectroscopic analysis. ${ }^{1-14}$ However, no clear boundaries exist distinguishing ternary surface complexes and surface precipitation, and these two terms sometimes are even used interchangeably. ${ }^{12}$ For example, surface precipitation was used to describe elevated $\mathrm{As}(\mathrm{V})$ removal in the presence of $\mathrm{Zn}^{11}$ and $\mathrm{Cu}^{15}$ on goethite. On the other hand, more recent reports use ternary surface complexation to describe the co-adsorption of cations and anions on a surface where the newly formed cation-anion solid phase does not grow beyond monolayer coverage. For instance, formation of a ternary surface complex enhanced $\mathrm{Cd}$ adsorption in the presence of $\mathrm{PO}_{4}$ and $\mathrm{SO}_{4}$ on goethite ${ }^{9,16}$ and ferrihydrite. ${ }^{17} \mathrm{In}$ addition, $\mathrm{SO}_{4}$ anions could form ternary surface complexes with $\mathrm{Pb}, \mathrm{Cu}$, and $\mathrm{Zn}$ on goethite, ${ }^{9,14}$ ferrihydrite, and schwertmannite. ${ }^{18}$ Although metal-As(V) ternary complexes on surfaces are wellknown, ${ }^{11,15,19}$ limited reports are available on metal-As(III) mutual effects on surfaces. ${ }^{19}$

The objective of this study was to explore the molecular-scale interactions of $\mathrm{As}(\mathrm{III})$ and $\mathrm{Cd}$ on $\mathrm{TiO}_{2}$ surfaces. To investigate the hypothesis that $\mathrm{As}(\mathrm{III})$ and $\mathrm{Cd}$ form a ternary surface complex on $\mathrm{TiO}_{2}$, multiple complementary techniques were used, including macroscopic adsorption/extraction experi-

Received: December 24, 2014

Revised: April 9, 2015

Accepted: April 29, 2015

Published: April 29, 2015 

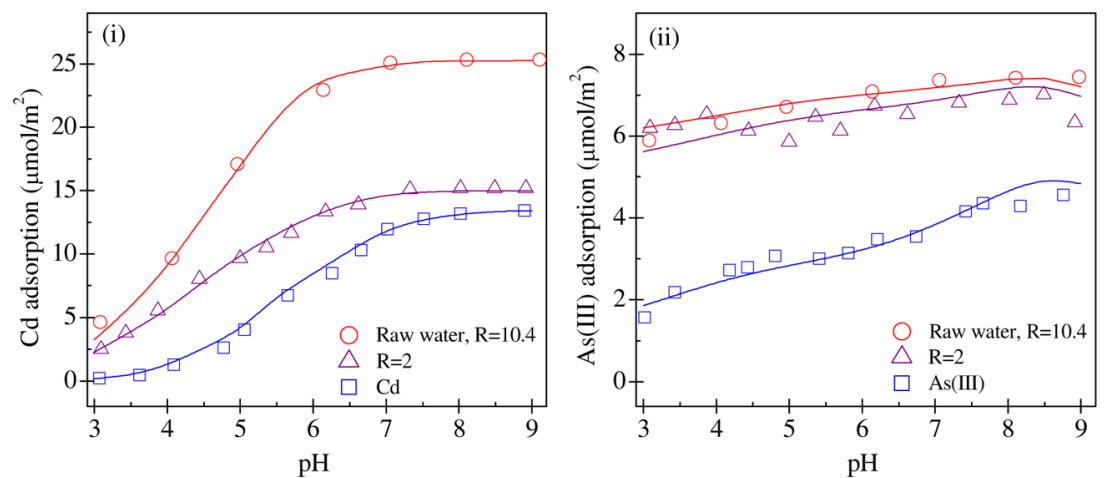

Figure 1. Experimental $\mathrm{pH}$ adsorption edges (symbols) and CD-MUSIC calculations (lines) of (i) Cd and (ii) As(III) in the simulated wastewater $[$ molar ratio of $\mathrm{As}(\mathrm{III}) / \mathrm{Cd}, R=2 ; \mathrm{As}(\mathrm{III})=5.26 \mathrm{mM}]$ and copper-smelting wastewater $[R=10.4$; As $(\mathrm{III})=51.52 \mathrm{mM}]$. The wastewater sample with the highest $\mathrm{Cd}$ concentration $(4.96 \mathrm{mM})$ was used to test the adsorption capacities under the worst scenarios.

ments, extended X-ray absorption fine structure (EXAFS) spectroscopy and in situ flow-cell attenuated total reflectance Fourier transform infrared (ATR-FTIR) spectroscopy analysis. The insights gained from this study should improve our knowledge in predicting the fate of neutral and cationic heavy metals.

\section{MATERIALS AND METHODS}

Materials. A wastewater sample containing an average concentration of $51.87 \mathrm{mM}(3890 \mathrm{mg} / \mathrm{L})$ As(III), $3.28 \mathrm{mM}$ $(369 \mathrm{mg} / \mathrm{L}) \mathrm{Cd}, 0.38 \mathrm{mM}(24 \mathrm{mg} / \mathrm{L}) \mathrm{Cu}$, and $0.02 \mathrm{mM}(5$ $\mathrm{mg} / \mathrm{L}) \mathrm{Pb}$ was obtained from a copper-smelting company in China. ${ }^{6}$ The As(III) concentration ranged from 50.93 to 52.41 $\mathrm{mM}$, and the Cd concentration varied from 2.48 to $4.96 \mathrm{mM}$. The average molar ratio of $\mathrm{As}(\mathrm{III}) / \mathrm{Cd}, R$, was 15.8 for the copper-smelting wastewater. The stock solutions of $13.35 \mathrm{mM}$ (1000 mg/L) As(III) and $8.90 \mathrm{mM}(1000 \mathrm{mg} / \mathrm{L}) \mathrm{Cd}$ were prepared by dissolving $\mathrm{NaAsO}_{2}$ and $\mathrm{Cd}\left(\mathrm{NO}_{3}\right)_{2}$ in deionized (DI) water, respectively. To prevent As(III) oxidation and to remove $\mathrm{CO}_{2}$, DI water was purged with nitrogen for at least 1 h. The nano- $\mathrm{TiO}_{2}$ was prepared by hydrolysis of titanyl sulfate, as described in our previous report. ${ }^{6}$ The Brunauer-EmmettTeller (BET) surface area was $196 \mathrm{~m}^{2} / \mathrm{g}$; the site density was 6 $\mathrm{mmol} / \mathrm{g}$; and the point of zero charge was 5.3.

Batch Experiments. Adsorption envelope experiments were performed to determine the adsorption edge, which is the amount of As(III) or Cd adsorbed as a function of the final solution $\mathrm{pH}$. Suspension samples containing As(III), Cd, and 1 $\mathrm{g} / \mathrm{L} \mathrm{TiO}_{2}$ were adjusted to desired $\mathrm{pH}$ values in the range of 39 with $\mathrm{NaOH}$ and $\mathrm{HClO}_{4}$. The initial $\mathrm{Cd}$ and As(III) concentrations in the binary and ternary adsorption systems were 2.63 and $5.26 \mathrm{mM}$, respectively, resulting in $R=2.0$. In a wastewater sample, the initial $\mathrm{Cd}$ and As(III) concentrations were 4.96 and $51.52 \mathrm{mM}$, respectively, leading to $R=10.4$. The highest $\mathrm{Cd}$ concentration $(4.96 \mathrm{mM})$ was selected to test the adsorption capacities under the worst scenarios. After the samples were mixed on a rotating shaker for $24 \mathrm{~h}$ in the dark, the final $\mathrm{pH}$ was measured and the suspension was passed through a $0.45 \mu \mathrm{m}$ membrane filter for measurements of soluble metals.

Analysis. The concentration of dissolved Cd was measured using a furnace atomic absorption spectrometer (FAAS) (AAS800, PerkinElmer, Waltham, MA). The As concentation and speciation were determined by a high-performance liquid chromatography atomic fluorescence spectrometry system (HPLC-AFS, Jitian, China) as detailed in our previous report. $^{20}$ The As speciation results confirm that no As(III) oxidation occurred during the experiments. Details of As speciation analysis, $\zeta$ potential measurement, surface-enhanced Raman scattering (SERS), EXAFS, ATR-FTIR, X-ray diffraction (XRD), scanning electron microscopy energydispersive X-ray spectroscopy (SEM-EDXS), surface complexation modeling, and quantum chemical calculations are reported in the Supporting Information.

\section{RESULTS AND DISCUSSION}

$\mathrm{pH}$ Dependence of $\mathrm{Cd}$ and $\mathrm{As}$ (III) Co-adsorption on $\mathrm{TiO}_{2}$. To investigate the $\mathrm{Cd}$ and $\mathrm{As}$ (III) removal under different $\mathrm{As}(\mathrm{III}) / \mathrm{Cd}$ molar ratios $(R)$, the $\mathrm{pH}$-dependent adsorption behaviors were studied in simulated wastewater $(R$ $=2)$ and copper-smelting wastewater $(R=10.4)$. The presence of $\mathrm{As}$ (III) (Figure 1i) substantially enhanced the $\mathrm{Cd}$ adsorption, and the $\mathrm{Cd}$ adsorption edges shifted to lower $\mathrm{pH}$ ranges with increasing $R$. The highest enhancement in $\mathrm{Cd}$ adsorption occurred in the copper-smelting wastewater with $51.52 \mathrm{mM} \mathrm{As}$ (III) and $4.96 \mathrm{mM} \mathrm{Cd}$ (Figure 1i) at $\mathrm{pH} 9$.

At $\mathrm{pH} 5-9$, the $\mathrm{Cd}$ adsorption increased from 4.0 to 13.4 $\mu \mathrm{mol} / \mathrm{m}^{2}$ in the $\mathrm{Cd}-\mathrm{TiO}_{2}$ binary system to $9.7-15.2$ and $17.1-25.2 \mu \mathrm{mol} / \mathrm{m}^{2}$ in the $\mathrm{Cd}-\mathrm{As}(\mathrm{III})-\mathrm{TiO}_{2}$ ternary system for simulated and smelting wastewater, respectively (Figure 1i). The site density of $\mathrm{TiO}_{2}$ is $6 \mathrm{mmol} / \mathrm{g}$, ${ }^{6}$ corresponding to a theoretical site concentration of $30.6 \mu \mathrm{mol} / \mathrm{m}^{2}$ in our system. This total available site, however, is not sufficient for Cd uptake $\left(17.1-25.2 \mu \mathrm{mol} / \mathrm{m}^{2}\right)$ from the wastewater if adsorption is the only removal mechanism, because one $\mathrm{Cd}$ atom should occupy two sites, as evidenced by our EXAFS study detailed in the following section. Therefore, other mechanisms besides adsorption must contribute to the $\mathrm{Cd}$ removal, such as the formation of surface precipitates or ternary surface complexes. In line with our results, elevated Cd adsorption in the presence of $\mathrm{As}(\mathrm{V})$ is observed and explained by electrostatic effects and the formation of a ternary $\mathrm{Cd}-\mathrm{As}(\mathrm{V})$-goethite complex. ${ }^{21}$ Meanwhile, a ternary surface complex of $\mathrm{Zn}$ and As on magnetite is also inferred as a possible mechanism for the enhanced adsorption of As and $\mathrm{Zn}{ }^{19}$

Similar to Cd adsorption, considerable enhancement in As(III) adsorption was observed in the presence of 2.63 and $4.96 \mathrm{mM} \mathrm{Cd}$ (Figure 1ii). For example, As(III) adsorption increased from $1.6 \mu \mathrm{mol} / \mathrm{m}^{2}$ in the $\mathrm{As}(\mathrm{III})-\mathrm{TiO}_{2}$ binary system to $4.6 \mu \mathrm{mol} / \mathrm{m}^{2}$ in the $\mathrm{Cd}-\mathrm{As}(\mathrm{III})-\mathrm{TiO}_{2}$ ternary system. Nevertheless, As(III) removal exhibited no significant difference $(p=0.052)$ when $R$ increased from 2 to 10.4. The 

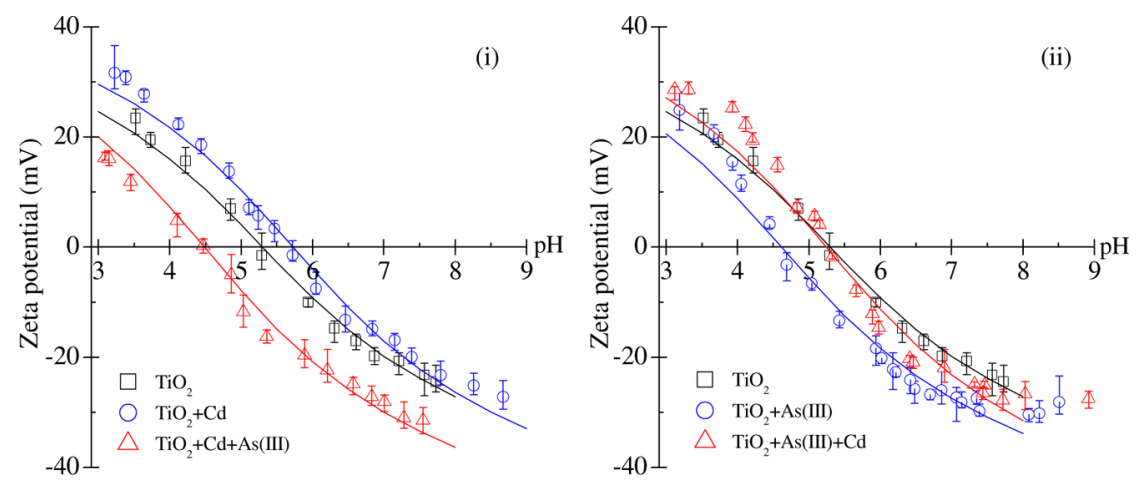

Figure 2. Experimental and CD-MUSIC simulations of $\zeta$ potential of $0.2 \mathrm{~g} / \mathrm{L} \mathrm{TiO}_{2}$ as the blank (black), $0.03 \mathrm{mM} \mathrm{As}(\mathrm{III})$ or Cd (red), and $0.03 \mathrm{mM}$ As(III) in the presence of $\mathrm{Cd}$ (blue) adsorbed $\mathrm{TiO}_{2}$ as a function of $\mathrm{pH}$ in $0.04 \mathrm{M} \mathrm{NaClO}_{4}$ solution. Error bars in (i) Cd and (ii) As(III) preadsorption systems represent the standard deviation $(n=3)$.

maximum adsorption of $\mathrm{As}(\mathrm{III})$ occurred at approximately $\mathrm{pH}$ 9, corresponding to the first dissociation constant of $\mathrm{H}_{3} \mathrm{AsO}_{3}$ $\left(\mathrm{p} K_{1}=9.3\right){ }^{22}$ In fact, this maximum As(III) adsorption (4.6 $\left.\mu \mathrm{mol} / \mathrm{m}^{2}\right)$ was substantially less than the theoretical site concentration of $\mathrm{TiO}_{2}\left(30.6 \mu \mathrm{mol} / \mathrm{m}^{2}\right)$.

The shift in the point of zero charge (PZC) of $\mathrm{TiO}_{2}$ (Figure 2 ) corresponded to the change in the adsorption curve. The PZC shifted from 5.3 for pristine $\mathrm{TiO}_{2}$ to approximately 5.7 upon $\mathrm{Cd}$ adsorption (Figure $2 \mathrm{i}$ ), indicating the formation of positively charged inner-sphere complexes on $\mathrm{TiO}_{2}{ }^{23}$ After the addition of $\mathrm{As}$ (III) to the $\mathrm{Cd}-\mathrm{TiO}_{2}$ system, the PZC moved to 4.4, suggesting that the As(III) uptake reduced the charge of the surface complex. Although soluble As(III) exists in the form of neutral $\mathrm{H}_{3} \mathrm{AsO}_{3}$ species below $\mathrm{pH}$ 9.3, the adsorption reaction may facilitate the deprotonation of the surface As(III) complex. ${ }^{23}$ A similar trend in the PZC shift was also observed in the As(III) pre-adsorption system (Figure 2ii): the PZC shifted first to 4.6 because of As(III) adsorption and then moved to 5.2 with the addition of $\mathrm{Cd}$. This charge neutralization signals the formation of the ternary surface complex. $^{12}$

One possibility for ternary surface complex formation is that the $\mathrm{Cd}-\mathrm{As}$ (III) aqueous complex may initially form in solution and then adsorb on the $\mathrm{TiO}_{2}$ surface as an assembly. To test such a premise, we used surface-enhanced Raman scattering (SERS) analysis because it provides an ultrasensitive probe of molecular structure. The lack of change in the As(III) characteristic peak at $726 \mathrm{~cm}^{-1}$ in the presence of $\mathrm{Cd}$ suggests that no Cd-As(III) complex was formed under the experimental conditions (see Figure S1 of the Supporting Information). Had aqueous $\mathrm{Cd}-\mathrm{As}$ (III) complexes formed, the As(III) symmetry and the As-O bond energy would be changed accordingly, which should result in a peak shift or split. $^{24}$

Arsenic K-Edge EXAFS Analysis. EXAFS spectroscopy was employed to determine the As local coordination environment on $\mathrm{TiO}_{2}$ in the presence of $\mathrm{Cd}$. Figure 3 presents the $k^{3}$-weighted As K-edge EXAFS spectra and corresponding Fourier transforms (FT) for the $\mathrm{Cd}-\mathrm{As}$ (III) precipitate, $\mathrm{As}(\mathrm{III})-\mathrm{TiO}_{2}$ binary, and $\mathrm{Cd}-\mathrm{As}(\mathrm{III})-\mathrm{TiO}_{2}$ ternary adsorption samples, and their fitting parameters are shown in Table S3 of the Supporting Information. The strong FT signal at $1.79 \AA$ was resolved corresponding to three As-O single scattering (SS) paths in the first shell for all samples.

A multiple scattering (MS) contribution corresponding to the As-O-O paths within the $\mathrm{AsO}_{3}$ pyramid was also
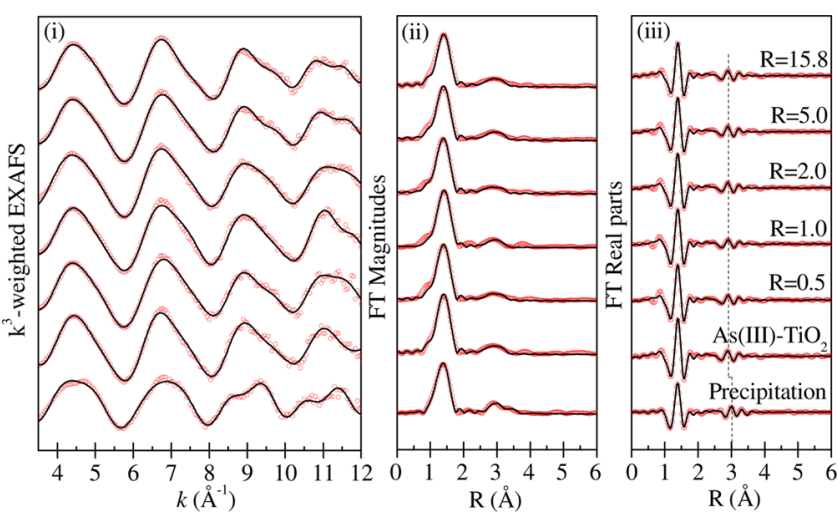

Figure 3. Observed (red circles) and fitted (black lines) (i) $k^{3}$ weighted As K-edge EXAFS spectra and their corresponding (ii) FT magnitudes and (iii) real parts. The precipitation sample was prepared by reacting $20 \mathrm{mM} \mathrm{As}(\mathrm{III})$ and $30 \mathrm{mM} \mathrm{Cd}$ at $\mathrm{pH} 5$ in $0.04 \mathrm{M} \mathrm{NaClO}_{4}$. The fitting parameters are shown in Table S3 of the Supporting Information, and the F-test results are shown in Table S4 of the Supporting Information. The binary $\mathrm{As}(\mathrm{III})-\mathrm{TiO}_{2}$ sample was prepared by mixing $2.0 \mathrm{mM}$ As(III) with $1 \mathrm{~g} / \mathrm{L} \mathrm{TiO}_{2}$ at $\mathrm{pH} 5.0$ in $0.04 \mathrm{M} \mathrm{NaClO}_{4}$. Spectra $R=0.5-15.8$ represent As(III) and Cd coadsorption on $\mathrm{TiO}_{2}$ at the $\mathrm{As}(\mathrm{III}) / \mathrm{Cd}$ ratios of $0.5,1.0,2.0,5.0$, and 15.8. The Cd concentration was $3.11 \mathrm{mM}$.

considered in the EXAFS fitting. Implementation of MS improved the fitting quality without adding extra variables because the MS parameters were constrained with the corresponding values of the As-O SS path.

In the Cd-As(III) precipitate sample (Figure 3), the second peak in the FT was attributed to an As-Cd SS path with a distance of $3.51 \AA$. Fitting this As-Cd peak was completed in both $k$ space and $R$ space using a single As-Cd shell, resulting in a coordination number $(\mathrm{CN})$ of 0.9 . Low $\mathrm{CN}$ less than unity has been reported in several studies ${ }^{25-28}$ and may be attributable to a monodentate mononuclear As complex with hydrogen bonding to an adjacent singly coordinated $\mathrm{OH}$ group. ${ }^{25}$ For example, $0.3 \mathrm{Fe}$ atoms at $2.94 \AA$ and $0.9 \mathrm{Fe}$ atoms at $3.37 \AA$ have been detected in a $\mathrm{Fe}(\mathrm{III})-\mathrm{As}(\mathrm{III})$ precipitate. $^{26}$

In the binary $\mathrm{As}(\mathrm{III})-\mathrm{TiO}_{2}$ adsorption sample, the second FT peak was ascribed to As-Ti bonding at $3.35 \AA$ with $1.8 \mathrm{Ti}$ atoms. The As-Ti distance and $\mathrm{CN}$ indicate the formation of a bidentate binuclear corner-sharing As complex on the $\mathrm{TiO}_{2}$ surface. $^{23}$

In the ternary $\mathrm{Cd}-\mathrm{As}(\mathrm{III})-\mathrm{TiO}_{2}$ adsorption samples, only SS paths, such as As-Ti (see Figure S2 and Table S1 of the 
Supporting Information) and As-Cd (see Figure S3 and Table S2 of the Supporting Information) were initially attempted to fit the second shell. However, these approaches resulted in unsatisfactory $R$ factors $(0.019-0.046)$. Then, mixed As-Ti and As-Cd paths were considered in the fit, and the model resolved 1.3-1.7 Ti atoms at the distance of 3.34-3.66 $\AA$ and 0.4-1.4 Cd atoms at the distance of 3.48-3.62 $\AA$ in the second shell (see Table S3 of the Supporting Information). Furthermore, the significance of adding an additional As-Cd path in ternary samples was justified using the $F$ test. $^{29,30}$ The $F$-test results show that the confidence level with the inclusion of the As-Cd SS path was 86.4-98.2\% (see Tables S4, S6, and S8 of the Supporting Information), significantly higher than the required value at $67 \%,{ }^{30}$ confirming the appropriateness of adding this As-Cd with the As-Ti path. Thus, the existence of an As-Cd bond suggests the formation of a ternary surface complex in the $\mathrm{Cd}-\mathrm{As}(\mathrm{III})-\mathrm{TiO}_{2}$ system. This ternary surface complex, corroborated by our density functional theory (DFT)optimized surface configuration (see Figure S18 and Table S15 of the Supporting Information), is proposed to explain the synergistic enhanced removal of $\mathrm{Cd}$ and $\mathrm{As}$ (III) from the smelting wastewater (Figure 1).

Cadmium K-Edge EXAFS Analysis. The $k^{3}$-weighted $\mathrm{Cd}$ K-edge EXAFS spectra and their FT as a function of the As(III) concentration are shown in Figure 4 and Table S9 of the

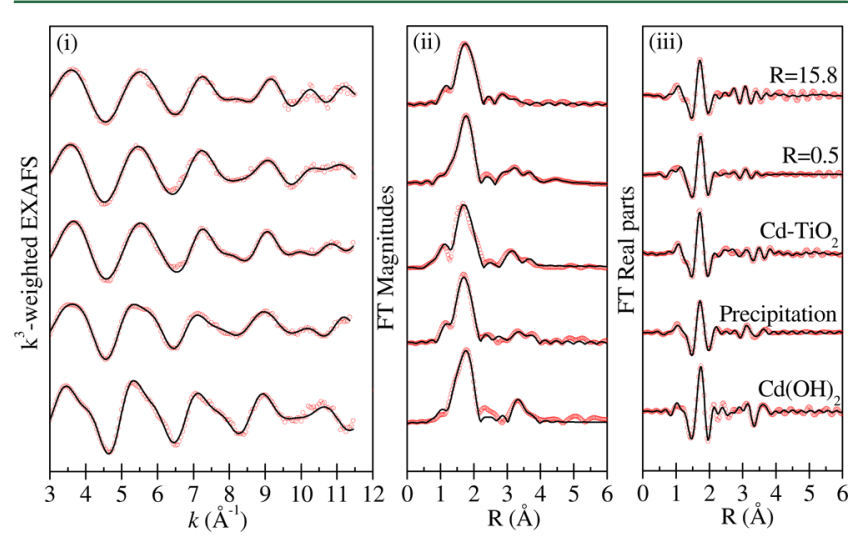

Figure 4. Observed (red circles) and fitted (black lines) (i) $k^{3}$ weighted $\mathrm{Cd} \mathrm{K}$-edge EXAFS spectra for binary $\mathrm{Cd}-\mathrm{TiO}_{2}$ and ternary $\mathrm{Cd}-\mathrm{As}(\mathrm{III})-\mathrm{TiO}_{2}$ systems and their corresponding (ii) FT magnitudes and (iii) real parts. The fitting parameters are shown in Table S9 of the Supporting Information, and the F-test results are shown in Table S10 of the Supporting Information. The $\mathrm{Cd}(\mathrm{OH})_{2}$ sample was prepared by reacting $31 \mathrm{mM} \mathrm{Cd}$ in $0.04 \mathrm{M} \mathrm{NaClO}_{4}$ solution at $\mathrm{pH} 12$. The precipitation sample was prepared by reacting $20 \mathrm{mM} \mathrm{As}$ (III) and $30 \mathrm{mM} \mathrm{Cd}$ in $0.04 \mathrm{M} \mathrm{NaClO}_{4}$ at $\mathrm{pH}$ 5. The binary $\mathrm{Cd}-\mathrm{TiO}_{2}$ sample was prepared by reacting $3.11 \mathrm{mM} \mathrm{Cd}\left(\mathrm{NO}_{3}\right)_{2}$ with $1 \mathrm{~g} / \mathrm{L} \mathrm{TiO}_{2}$ at pH 5.0 in $0.04 \mathrm{M} \mathrm{NaClO}_{4}$. Spectra $R=0.5$ and 15.8 represent ternary $\mathrm{Cd}-\mathrm{As}(\mathrm{III})-\mathrm{TiO}_{2}$ adsorption samples with the As(III)/Cd molar ratio of 0.5 and 15.8 , respectively. The Cd concentration was $3.11 \mathrm{mM}$.

Supporting Information. The spectra of $\mathrm{Cd}(\mathrm{OH})_{2}$ precipitation, $\mathrm{Cd}-\mathrm{As}(\mathrm{III})$ precipitation, and binary $\mathrm{Cd}-\mathrm{TiO}_{2}$ adsorption samples were also collected as controls. In these samples, the first and strongest peak in the FT curve was contributed by six oxygen atoms at distances of 2.26-2.29 $\AA$ (Figure 4 and Table S9 of the Supporting Information). This $\mathrm{Cd}-\mathrm{O}$ octahedral structure is in line with published results. ${ }^{31,32}$ In the precipitate samples, $\mathrm{Cd}-\mathrm{Cd}$ paths were observed at the distance of $3.54 \AA$ with $8.8 \mathrm{Cd}$ atoms for $\mathrm{Cd}(\mathrm{OH})_{2}$ and $3.61 \AA$ with $1.1 \mathrm{Cd}$ atoms for $\mathrm{Cd}-\mathrm{As}(\mathrm{III})$ precipitates, which were comparable with previous studies. ${ }^{33,34}$

In the $\mathrm{Cd}-\mathrm{As}(\mathrm{III})-\mathrm{TiO}_{2}$ samples, no $\mathrm{Cd}-\mathrm{Cd}$ paths were detected, indicating that no $\mathrm{Cd}(\mathrm{OH})_{2}$ or $\mathrm{Cd}-\mathrm{As}(\mathrm{III})$ precipitates existed (Table $S 9$ of the Supporting Information) ${ }^{32}$ When the As(III) concentration was low $(R=0.5), \mathrm{Cd}$ bonded with $0.6 \mathrm{Ti}$ and $0.5 \mathrm{As}$ atoms, while in the presence of elevated concentrations of As(III) $(R=15.8)$, only 0.6 As atoms were resolved in the second shell around each $\mathrm{Cd}$ atom. The confidence levels for the existence of a Cd-Ti SS path in low As(III) concentration samples were 93.4-99.3\%, as determined with the $F$ test, whereas in the high As(III) concentration samples, the addition of a Cd-Ti SS path led to unacceptable $R$ factors (see Table $S 10$ of the Supporting Information). The absence of $\mathrm{Ti}$ in the second shell indicated that $\mathrm{Cd}$ could not be directly attached to $\mathrm{TiO}_{2}$ at high $\mathrm{As}$ (III) levels. Thus, in comparison to $\mathrm{As}(\mathrm{III}), \mathrm{Cd}$ had a lower affinity for $\mathrm{TiO}_{2}$ surfaces. The synergistic removal of $\mathrm{Cd}$, therefore, could be mainly ascribed to the formation of a $\mathrm{Cd}-\mathrm{As}$ (III)$\mathrm{TiO}_{2}$ ternary surface complex.

To investigate the effect of contact sequence on the surface configuration, As(III) (or Cd) was pre-adsorbed on $\mathrm{TiO}_{2}$ before contact with $\mathrm{Cd}$ [or As(III)]. The EXAFS results in Figures S4-S6 and Tables S5-S12 of the Supporting Information show that, regardless of the adsorption sequence, As(III) had a higher priority for adsorption on $\mathrm{TiO}_{2}$ than $\mathrm{Cd}$. These contact sequence results and Cd K-edge EXAFS analysis consistently suggest that As(III) has a higher affinity for $\mathrm{TiO}_{2}$, and the $\mathrm{Cd}-\mathrm{As}(\mathrm{III})-\mathrm{TiO}_{2}$ ternary surface complex should be formed with the adsorbed As(III) as the bridging molecule.

The DFT-optimized clusters of $\mathrm{Ti}_{2} \mathrm{AsO}_{15} \mathrm{H}_{19}$ and $\mathrm{Ti}_{2} \mathrm{AsO}_{16} \mathrm{CdH}_{19}$ (see Figure $\mathrm{S} 18$ of the Supporting Information) were in agreement with the EXAFS results, as evidenced by their similar As-O, As-Ti, and As-Cd interatomic distances (see Table S15 of the Supporting Information). In accordance with our EXAFS results, the DFT-calculated configuration of the As(III) surface complex remained unchanged during the formation of the ternary surface complex.

Surface Complexation and Precipitation. The XRD analysis shows that a $\mathrm{Cd}-\mathrm{As}$ (III) surface precipitate may form at high $\mathrm{Cd}$ and $\mathrm{As}(\mathrm{III})$ concentrations at elevated $\mathrm{pH}$ (see Figure S7-S11 of the Supporting Information). However, the surface precipitation may not be the primary mechanism for As(III) and Cd removal from wastewater. The SEM-EDXS analysis showed that the atomic As/Cd ratio (7.36) in the wastewater adsorption sample was much higher than that in the $\mathrm{Cd}-\mathrm{As}$ (III) precipitate, which is about 1 (see Figures S12 and S13 and Table S13 of the Supporting Information). If surface precipitation was the dominate mechanism in $\mathrm{As}(\mathrm{III})$ and $\mathrm{Cd}$ removal from wastewater samples, the atomic As/Cd ratio should be close to the $\mathrm{Cd}-\mathrm{As}$ precipitate. In the wastewater sample, the high atomic As/Cd ratio may be ascribed to the high As(III) adsorption density on $\mathrm{TiO}_{2}$. The results indicate that adsorption and ternary surface complexation could be the major process for As(III) and Cd removal.

The formation of a surface ternary complex might be a prerequisite and starting point for the nucleation process of surface precipitation. ${ }^{35}$ Thus, the Cd-As(III) surface complex and then precipitate could be formed on $\mathrm{TiO}_{2}$, even with concentrations of $\mathrm{Cd}$ and $\mathrm{As}$ (III) appreciably lower than their supersaturation condition. The presence of $\mathrm{TiO}_{2}$ greatly enhanced $\mathrm{Cd}$ and $\mathrm{As}(\mathrm{III})$ removal compared to precipitation 
samples, especially at $\mathrm{pH}<7$ (see Figure S14 of the Supporting Information).

ATR-FTIR Study. In situ flow-cell ATR-FTIR was used to probe the surface reactions of $\mathrm{As}$ (III) and $\mathrm{Cd}$ on $\mathrm{TiO}_{2}$. The FTIR spectra of As(III) and Cd pre-adsorption as a function of As(III)/Cd molar ratio $(R)$ are shown for $R=0.5-15.8$ in Figure 5, and the corresponding FTIR spectra in time series are

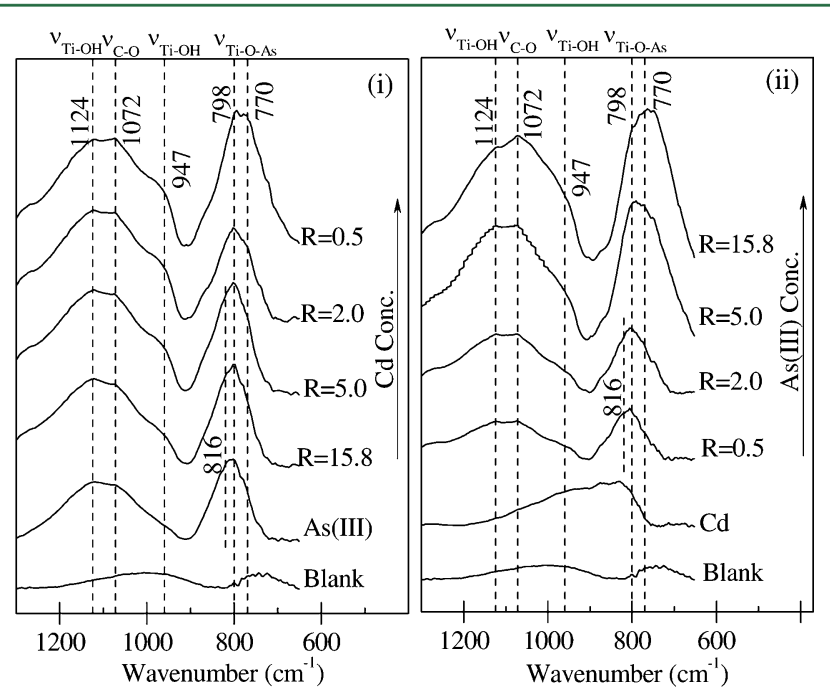

Figure 5. FTIR spectra of (i) $\mathrm{As}(\mathrm{III})$ and (ii) Cd pre-adsorbed $\mathrm{TiO}_{2}$ film at $\mathrm{pH} 5.0$ in $0.04 \mathrm{M} \mathrm{NaCl}$ solution. For As(III) pre-adsorption, the solution consisted of the $\mathrm{As}(\mathrm{III})$ concentration $(0.67 \mathrm{mM})$ and various $\mathrm{Cd}$ concentrations (0.34-10.59 mM; $R=0.5-15.8)$. For $\mathrm{Cd}$ pre-adsorption, the solution consisted of the $\mathrm{Cd}$ concentration (0.44 $\mathrm{mM})$ and various $\mathrm{As}(\mathrm{III})$ concentrations $(0.22-6.95 \mathrm{mM} ; R=0.5-$ 15.8). The spectrum was equilibrated on $\mathrm{TiO}_{2}$ film for $3 \mathrm{~h}$, and the blank was taken after the $0.04 \mathrm{M} \mathrm{NaCl}$ solution flowed over the $\mathrm{TiO}_{2}$ film for $3 \mathrm{~h}$

shown in Figure S15 of the Supporting Information. The details of peak assignments are shown in Figures S16 and S17 and Table S14 of the Supporting Information. The initial concentration of As(III) was $0.67 \mathrm{mM}$ because the As(III) peak could not be detected below this concentration.

Two groups of peaks were detected in the range of 1200900 and $900-750 \mathrm{~cm}^{-1}$ (Figure 5). The first group consisted of three peaks that are not directly associated with As-O vibrations: the mixed $\mathrm{OH}$ vibrations of $\mathrm{TiOOH}^{36,37}$ and AsOH (see Table S14 of the Supporting Information) at 1124 $\mathrm{cm}^{-1}$, the Ti-O vibration at $947 \mathrm{~cm}^{-1}, 37$ and the unidentate carbonate vibration at $1072 \mathrm{~cm}^{-1} \cdot 38,39 \mathrm{CO}_{2}$ can be adsorbed on $\mathrm{TiO}_{2}$ during drying in preparation of the film, and its surface structure changed from bidentate to unidentate upon As(III) adsorption. This structural change was evidenced by the negative peaks at 1685 and $1570 \mathrm{~cm}^{-1}$ because of the loss of bidentate carbonate ${ }^{38,39}$ and the positive peak at $1072 \mathrm{~cm}^{-1}$ from unidentate carbonate adsorption (see Figure S17 of the Supporting Information). Moreover, the intensity of this group of peaks increased as a function of the reaction time (see Figure S15 of the Supporting Information), confirming that these peaks were induced by As(III) adsorption.

The second group of peaks in the range of $900-750 \mathrm{~cm}^{-1}$ was directly associated with As-O vibrations. When As(III) was pre-adsorbed on $\mathrm{TiO}_{2}$, a peak at $798 \mathrm{~cm}^{-1}$ and a shoulder at $770 \mathrm{~cm}^{-1}$ were observed because of the $\mathrm{Ti}-\mathrm{O}-$ As stretching vibration (Figure 5i), which agrees well with previous studies. ${ }^{40-42}$ In addition, a shoulder at $816 \mathrm{~cm}^{-1}$ was exhibited because of the asymmetric stretching of $\mathrm{As}(\mathrm{III})-\mathrm{OH}^{43}$ In line with our FTIR results, our DFT calculations resolved the Ti$\mathrm{O}-$ As stretching vibrations at 773 and $816 \mathrm{~cm}^{-1}$ and the uncomplexed As(III)-OH stretching vibration at $827 \mathrm{~cm}^{-1}$ (see Table S16 of the Supporting Information).

With the $\mathrm{Cd}$ solution flowed through over this As preadsorbed $\mathrm{TiO}_{2}$ film, the intensity of the As(III)-OH peak at $816 \mathrm{~cm}^{-1}$ decreased and became imperceptible at high $\mathrm{Cd}$ concentrations (Figure $5 \mathrm{i}$ ). At low $\mathrm{Cd}$ concentrations, i.e., $R=$ 15.8-5.0, only part of the surface $\mathrm{Ti}-\mathrm{O}-\mathrm{As}$ complexes were associated with $\mathrm{Cd}$, resulting in some dangling $\mathrm{As}(\mathrm{III})-\mathrm{OH}$ bonds. With a further increase in the Cd concentration, i.e., $R=$ 2.0-0.5, Cd may occupy almost all of the $\mathrm{Ti}-\mathrm{O}-$ As complex sites, leading to the disappearance of the uncomplexed $\mathrm{As}$ (III) $-\mathrm{OH}$ vibration at $816 \mathrm{~cm}^{-1}$ (Figure 5i). This extinction of the As(III)-OH peak indicates that the initially formed As(III) bidentate binuclear surface complex changes its $C_{s}$ symmetry ${ }^{23}$ when transforming into the $\mathrm{Ti}-\mathrm{O}-\mathrm{As}-\mathrm{O}-\mathrm{Cd}$ ternary complex. ${ }^{13,14}$ Similar results have been reported when a ternary $\mathrm{Ca}$ and phosphate complex formed on $\mathrm{TiO}_{2}$ : the phosphate adsorption peak at about $1100 \mathrm{~cm}^{-1}$ disappeared with the addition of $\mathrm{Ca}$, implying that the adsorbed phosphate symmetry changed from $C_{2 v}$ to $C_{3 v^{*}}{ }^{44}$ In agreement with our FTIR results, our DFT calculations also justified the ternary complex formation with two notable observations. First, the $\mathrm{As}(\mathrm{III})-\mathrm{OH}$ vibration at $816 \mathrm{~cm}^{-1}$ in the binary $\mathrm{As}(\mathrm{III})-\mathrm{TiO}_{2}$ cluster was not resolved in the $\mathrm{Ti}-\mathrm{O}-\mathrm{As}-\mathrm{O}-\mathrm{Cd}$ ternary complex (see Figure S18 and Table S16 of the Supporting Information). Second, two peaks at 773 and $790 \mathrm{~cm}^{-1}$, corresponding to the experimental observations of bands at 770 and $798 \mathrm{~cm}^{-1}$ because of $\mathrm{Ti}-\mathrm{O}-\mathrm{As}$ vibrations, were resolved in the ternary complex (see Figure S18 and Table S16 of the Supporting Information). Moreover, the peak intensities at 770 and $798 \mathrm{~cm}^{-1}$ increased as a function of the $\mathrm{Cd}$ concentration (Figure 5i), which is in line with the enhanced As(III) adsorption in the presence of Cd (Figure 1ii). Increased inner-sphere adsorption peak intensities have been observed when $\mathrm{SO}_{4} / \mathrm{PO}_{4}$ and $\mathrm{Cd}$ ternary surface complexes formed on iron oxides. ${ }^{13,16}$

When $\mathrm{Cd}$ was pre-adsorbed on $\mathrm{TiO}_{2}$, a broad peak in the range of $750-1100 \mathrm{~cm}^{-1}$ was detected (Figure 5ii). With the introduction of As(III), vibrations of $\mathrm{Ti}-\mathrm{O}-\mathrm{As}$ (770 and 798 $\left.\mathrm{cm}^{-1}\right)$ and $\mathrm{As}(\mathrm{III})-\mathrm{OH}\left(816 \mathrm{~cm}^{-1}\right)$ were detected at $R=0.5-$ 2.0, which agrees with As(III) pre-adsorption samples (Figure 5i). Interestingly, the broad peak because of $\mathrm{Cd}$ adsorption disappeared upon the uptake of As(III), indicating the desorption of $\mathrm{Cd}$. With the further increase in the As(III) concentration, i.e., $R=5.0-15.8$, the peak at $816 \mathrm{~cm}^{-1}$ because of As(III)-OH vibration was indiscernible, implying that this dangling bond was complexed with $\mathrm{Cd}$ to form the $\mathrm{Ti}-\mathrm{O}-\mathrm{As}-$ $\mathrm{O}-\mathrm{Cd}$ ternary complex.

In combination with the EXAFS results, our FTIR and DFT results show that As(III) may be preferentially adsorbed on $\mathrm{TiO}_{2}$ rather than $\mathrm{Cd}$. At low As(III) concentrations, $\mathrm{Cd}-\mathrm{O}-\mathrm{Ti}$ and $\mathrm{Cd}-\mathrm{O}-\mathrm{As}$ bonds were formed, indicating that both binary and ternary surface complexes exist on the $\mathrm{TiO}_{2}$ surface. Conversely, at high As(III) concentrations, only a Cd-O-As bond was detected by EXAFS and the As(III)-OH vibration disappeared, suggesting the formation of the ternary surface complex. This ternary surface complex could form over a wide $\mathrm{As}$ (III) and Cd concentration range to achieve their synergistic removal. 
Surface Complexation Modeling and Ternary Surface Complex. The charge distribution multi-site complexation (CD-MUSIC) modeling is a powerful tool to interpret macroscopic observations under the constraint of molecularlevel spectroscopic results. Thus, on the basis of our EXAFS and FTIR results, the bidentate binuclear complexes $\mathrm{Ti}_{2} \mathrm{O}_{2} \mathrm{AsO}^{-5 / 3}$ and $\mathrm{Ti}_{2} \mathrm{O}_{2} \mathrm{Cd}\left(\mathrm{H}_{2} \mathrm{O}\right)_{4}^{-2 / 3}$ were used in CDMUSIC to simulate binary As- $\mathrm{TiO}_{2}$ and $\mathrm{Cd}-\mathrm{TiO}_{2}$ adsorption systems, respectively. In addition, a ternary surface complex, $\mathrm{Ti}_{2} \mathrm{O}_{2} \mathrm{AsOCd}^{1 / 3}$, was included in CD-MUSIC for the ternary $\mathrm{Cd}-\mathrm{As}(\mathrm{III})-\mathrm{TiO}_{2}$ system, as evidenced by the spectroscopic analysis (see Table S17 of the Supporting Information). With the inclusion of these surface species, our CD-MUSIC modeling results agreed well with the experimental adsorption edge curves and $\zeta$ potential shift (Figures 1 and 2 ) and confirmed that the synergistic uptake of $\mathrm{Cd}$ and $\mathrm{As}(\mathrm{III})$ was mainly due to the formation of the ternary surface complex. In agreement with our present study, ternary surface complexes have been successfully used to simulate the co-adsorption of $\mathrm{Cu}, \mathrm{Zn}, \mathrm{Pb}$, and $\mathrm{Cd}$ with $\mathrm{SO}_{4}$ on ferrihydrite, schwertmannite, and goethite. ${ }^{9,18}$

Release of As and Cd from Binary and Ternary Surface Complexation Samples. The potentially different impacts of binary and ternary surface complexes on the mobility of $\mathrm{Cd}$ and $\mathrm{As}(\mathrm{III})$ motivated our further study using extraction experiments. The release of $\mathrm{Cd}$ and $\mathrm{As}$ (III) followed the pseudo-second-order kinetics model (see Figures S19 and S20 and Table S18 and S19 of the Supporting Information). The leaching results show that $0.2-5.5 \% \mathrm{Cd}$ and $3.2-20.1 \%$ $\mathrm{As}(\mathrm{III})$ were released in the ternary $\mathrm{Cd}-\mathrm{As}(\mathrm{III})-\mathrm{TiO}_{2}$ system, appreciably less than that in binary adsorption systems (2.3$15.5 \% \mathrm{Cd}$ and $7.6-46.3 \%$ As; see Figure $\mathrm{S} 19$ of the Supporting Information). In the $\mathrm{pH}$ range of $2-12$, the $\mathrm{Cd}-\mathrm{As}(\mathrm{III})-\mathrm{TiO}_{2}$ ternary complex was more stable than binary $\mathrm{As}(\mathrm{III})-\mathrm{TiO}_{2}$ and $\mathrm{Cd}-\mathrm{TiO}_{2}$ complexes, as evidenced by its lower desorption ratio (see Figure S21 of the Supporting Information).

The formation of the ternary surface complex significantly increased $\mathrm{Cd}$ and $\mathrm{As}$ (III) adsorption capacities on metal oxides. With the enrichment of $\mathrm{Cd}$ and $\mathrm{As}(\mathrm{III})$ on $\mathrm{TiO}_{2}$, surface precipitates might be subsequently formed and the occurrence of metal-As precipitates would generally lower their mobility and bioavailability. This hypothesis has been supported by the $\mathrm{Zn}-\mathrm{As}(\mathrm{V})$ co-precipitation on goethite samples with reduced leachability. ${ }^{11}$ Similarly, the adsorption and surface precipitation of As(III) with Fe(II, III) could dramatically reduce the solubility of As(III) under anoxic conditions. ${ }^{26}$

\section{ASSOCIATED CONTENT}

\section{S Supporting Information}

Details of As speciation analysis, $\zeta$ potential measurement, SERS, EXAFS, ATR-FTIR, XRD, SEM-EDXS, surface complexation modeling, and quantum chemical calculation results, with additional figures and tables. The Supporting Information is available free of charge on the ACS Publications website at DOI: 10.1021 /es5062903.

\section{AUTHOR INFORMATION}

\section{Corresponding Authors}

*E-mail: chan.ts@nsrrc.org.tw.

*Telephone/Fax: +86-10-6284-9523. E-mail: cyjing@rcees.ac. cn.

\section{Notes}

The authors declare no competing financial interest.

\section{ACKNOWLEDGMENTS}

The authors acknowledge the financial support of the National Basic Research Program of China (2015CB932003), the Strategic Priority Research Program of the Chinese Academy of Sciences (XDB14020201), the National Natural Science Foundation of China (41373123, 41425016, and 21321004), and the Research Center for Eco-Environmental Sciences (RCEES) (YSW2013A01). The EXAFS spectra were acquired at the National Synchrotron Radiation Research Center (NSRRC) BL01C1.

\section{REFERENCES}

(1) Nakajima, K.; Takeda, O.; Miki, T.; Matsubae, K.; Nagasaka, T. Thermodynamic analysis for the controllability of elements in the recycling process of metals. Environ. Sci. Technol. 2011, 45, 49294936.

(2) Bian, Z. F.; Miao, X. X.; Lei, S. G.; Chen, S. E.; Wang, W. F.; Struthers, $S$. The challenges of reusing mining and mineral-processing wastes. Science 2012, 337, 702-703.

(3) Wang, S.; Xu, L.; Zhao, Z.; Wang, S.; Jia, Y.; Wang, H.; Wang, X. Arsenic retention and remobilization in muddy sediments with high iron and sulfur contents from a heavily contaminated estuary in China. Chem. Geol. 2012, 314, 57-65.

(4) Kumar, P. S.; Onnby, L.; Kirsebom, H. Arsenite adsorption on cryogels embedded with iron-aluminium double hydrous oxides: Possible polishing step for smelting wastewater? J. Hazard. Mater. 2013, 250, 469-476.

(5) Bednar, A. J.; Garbarino, J. R.; Ranville, J. F.; Wildeman, T. R. Preserving the distribution of inorganic arsenic species in groundwater and acid mine drainage samples. Environ. Sci. Technol. 2002, 36, 22132218.

(6) Luo, T.; Cui, J.; Hu, S.; Huang, Y.; Jing, C. Arsenic removal and recovery from copper smelting wastewater using $\mathrm{TiO}_{2}$. Environ. Sci. Technol. 2010, 44, 9094-9098.

(7) Erskine, P.; Van der Ent, A.; Fletcher, A. Sustaining metal-loving plants inmining regions. Science 2012, 337, 1172-1173.

(8) Beattie, D. A.; Chapelet, J. K.; Grafe, M.; Skinner, W. M.; Smith, E. In situ ATR FTIR studies of $\mathrm{SO}_{4}$ adsorption on goethite in the presence of copper ions. Environ. Sci. Technol. 2008, 42, 9191-9196.

(9) Swedlund, P. J.; Webster, J. G.; Miskelly, G. M. Goethite adsorption of $\mathrm{Cu}(\mathrm{II}), \mathrm{Pb}(\mathrm{II}), \mathrm{Cd}(\mathrm{II})$, and $\mathrm{Zn}(\mathrm{II})$ in the presence of sulfate: Properties of the ternary complex. Geochim. Cosmochim. Acta 2009, 73, 1548-1562.

(10) Collins, C. R.; Ragnarsdottir, K. V.; Sherman, D. M. Effect of inorganic and organic ligands on the mechanism of cadmium sorption to goethite. Geochim. Cosmochim. Acta 1999, 63, 2989-3002.

(11) Grafe, M.; Nachtegaal, M.; Sparks, D. L. Formation of metalarsenate precipitates at the goethite-water interface. Environ. Sci. Technol. 2004, 38, 6561-670.

(12) Ler, A.; Stanforth, R. Evidence for surface precipitation of phosphate on goethite. Environ. Sci. Technol. 2003, 37, 2694-2700.

(13) Elzinga, E. J.; Kretzschmar, R. In situ ATR-FTIR spectroscopic analysis of the co-adsorption of orthophosphate and $\mathrm{Cd}(\mathrm{II})$ onto hematite. Geochim. Cosmochim. Acta 2013, 117, 53-64.

(14) Elzinga, E. J.; Peak, D.; Sparks, D. L. Spectroscopic studies of $\mathrm{Pb}(\mathrm{II})$-sulfate interactions at the goethite-water interface. Geochim. Cosmochim. Acta 2001, 65, 2219-2230.

(15) Grafe, M.; Beattie, D. A.; Smith, E.; Skinner, W. M.; Singh, B. Copper and arsenate co-sorption at the mineral-water interfaces of goethite and jarosite. J. Colloid Interface Sci. 2008, 322, 399-413.

(16) Zhang, G. Y.; Peak, D. Studies of Cd(II)-sulfate interactions at the goethite-water interface by ATR-FTIR spectroscopy. Geochim. Cosmochim. Acta 2007, 71, 2158-2169. 
(17) Swedlund, P. J.; Webster, J. G.; Miskelly, G. M. The effect of $\mathrm{SO}_{4}$ on the ferrihydrite adsorption of $\mathrm{Co}, \mathrm{Pb}$ and $\mathrm{Cd}$ : Ternary complexes and site heterogeneity. Appl. Geochem. 2003, 18, 16711689.

(18) Swedlund, P. J.; Webster, J. G. Cu and $\mathrm{Zn}$ ternary surface complex formation with $\mathrm{SO}_{4}$ on ferrihydrite and schwertmannite. Appl. Geochem. 2001, 16, 503-511.

(19) Yang, W. C.; Kan, A. T.; Chen, W.; Tomson, M. B. pHdependent effect of zinc on arsenic adsorption to magnetite nanoparticles. Water Res. 2010, 44, 5693-5701.

(20) Cui, J.; Shi, J.; Jiang, G.; Jing, C. Arsenic levels and speciation from ingestion exposures to biomarkers in Shanxi, China: Implications for human health. Environ. Sci. Technol. 2013, 47, 5419-5424.

(21) Jiang, W.; Lv, J.; Luo, L.; Yang, K.; Lin, Y.; Hu, F.; Zhang, J.; Zhang, S. Arsenate and cadmium co-adsorption and co-precipitation on goethite. J. Hazard. Mater. 2013, 262, 55-63.

(22) Meng, X.; Bang, S.; Korfiatis, G. P. Effects of silicate, sulfate, and carbonate on arsenic removal by ferric chloride. Water Res. 2000, 34, $1255-1261$.

(23) Pena, M.; Meng, X. G.; Korfiatis, G. P.; Jing, C. Y. Adsorption mechanism of arsenic on nanocrystalline titanium dioxide. Environ. Sci. Technol. 2006, 40, 1257-1262.

(24) Du, J.; Cui, J.; Jing, C. Rapid in situ identification of arsenic species using a portable $\mathrm{Fe}_{3} \mathrm{O}_{4} @ \mathrm{Ag}$ SERS sensor. Chem. Commun. 2014, 50, 347-349.

(25) Mikutta, C.; Kretzschmar, R. Spectroscopic evidence for ternary complex formation between arsenate and ferric iron complexes of humic substances. Environ. Sci. Technol. 2011, 45, 9550-9557.

(26) Wang, Y.; Morin, G.; Ona-Nguema, G.; Menguy, N.; Juillot, F.; Aubry, E.; Guyot, F.; Calas, G.; Brown, G. E., Jr. Arsenite sorption at the magnetite-water interface during aqueous precipitation of magnetite: EXAFS evidence for a new arsenite surface complex. Geochim. Cosmochim. Acta 2008, 72, 2573-2586.

(27) Ona-Nguema, G.; Morin, G.; Juillot, F.; Calas, G.; Brown, G. E. EXAFS analysis of arsenite adsorption onto two-line ferrihydrite, hematite, goethite, and lepidocrocite. Environ. Sci. Technol. 2005, 39, 9147-9155.

(28) Morin, G.; Wang, Y.; Ona-Nguema, G.; Juillot, F.; Calas, G.; Menguy, N.; Aubry, E.; Bargar, J. R.; Brown, G. E., Jr. EXAFS and HRTEM evidence for As(III)-containing surface precipitates on nanocrystalline magnetite: Implications for As sequestration. Langmuir 2009, 25, 9119-9128.

(29) Klementev, K. V. Statistical evaluations in fitting problems. J. Synchrotron Radiat. 2001, 8, 270-272.

(30) Downward, L.; Booth, C. H.; Lukens, W. W.; Bridges, F. A variation of the F-test for determining statistical relevance of particular parameters in EXAFS fits. In X-Ray Absorption Fine StructureXAFS13: 13th International Conference: Stanford, California, USA, 9-14 July, 2006; Hedman, B., Painetta, P., Eds.; American Institute of Physics: College Park, MD, 2007; Vol. 882, pp 129-131.

(31) Ramstedt, M.; Norgren, C.; Shchukarev, A.; Sjoberg, S.; Persson, P. Co-adsorption of cadmium(II) and glyphosate at the watermanganite $(\gamma-\mathrm{MnOOH})$ interface. J. Colloid Interface Sci. 2005, 285, 493-501.

(32) Vasconcelos, I. F.; Haack, E. A.; Maurice, P. A.; Bunker, B. A. EXAFS analysis of cadmium(II) adsorption to kaolinite. Chem. Geol. 2008, 249, 237-249.

(33) Randall, S. R.; Sherman, D. M.; Ragnarsdottir, K. V.; Collins, C. R. The mechanism of cadmium surface complexation on iron oxyhydroxide minerals. Geochim. Cosmochim. Acta 1999, 63, 29712987.

(34) Bochatay, L.; Persson, P.; Sjoberg, S. Metal ion coordination at the water-manganite $(\gamma-\mathrm{MnOOH})$ interface I. An EXAFS study of cadmium(II). J. Colloid Interface Sci. 2000, 229, 584-592.

(35) Stumm, W. Chemistry of the Solid-Water Interface; WileyInterscience: New York, 1999.

(36) Nakamura, R.; Imanishi, A.; Murakoshi, K.; Nakato, Y. In situ FTIR studies of primary intermediates of photocatalytic reactions on nanocrystalline $\mathrm{TiO}_{2}$ films in contact with aqueous solutions. J. Am. Chem. Soc. 2003, 125, 7443-7450.

(37) Roddick-Lanzilotta, A. D.; Connor, P. A.; McQuillan, A. J. An in situ infrared spectroscopic study of the adsorption of lysine to $\mathrm{TiO}_{2}$ from an aqueous solution. Langmuir 1998, 14, 6479-6484.

(38) Liao, L. F.; Lien, C. F.; Shieh, D. L.; Chen, M. T.; Lin, J. L. FTIR study of adsorption and photoassisted oxygen isotopic exchange of carbon monoxide, carbon dioxide, carbonate, and formate on $\mathrm{TiO}_{2}$. J. Phys. Chem. B 2002, 106, 11240-11245.

(39) Wijnja, H.; Schulthess, C. P. Carbonate adsorption mechanism on goethite studied with ATR-FTIR, DRIFT, and proton coadsorption measurements. Soil Sci. Soc. Am. J. 2001, 65, 324-330.

(40) Parikh, S. J.; Lafferty, B. J.; Sparks, D. L. An ATR-FTIR spectroscopic approach for measuring rapid kinetics at the mineral/ water interface. J. Colloid Interface Sci. 2008, 320, 177-185.

(41) Voegelin, A.; Hug, S. J. Catalyzed oxidation of arsenic(III) by hydrogen peroxide on the surface of ferrihydrite: An in situ ATRFTIR study. Environ. Sci. Technol. 2003, 37, 972-978.

(42) Bhandari, N.; Reeder, R. J.; Strongin, D. R. Photoinduced oxidation of arsenite to arsenate on ferrihydrite. Environ. Sci. Technol. 2011, 45, 2783-2789.

(43) Zheng, Y.-M.; Yu, L.; Wu, D.; Chen, J. P. Removal of arsenite from aqueous solution by a zirconia nanoparticle. Chem. Eng. J. 2012, $188,15-22$.

(44) Ronson, T. K.; McQuillan, A. J. Infrared spectroscopic study of calcium and phosphate ion coadsorption and of brushite crystallization on $\mathrm{TiO}_{2}$. Langmuir 2002, 18, 5019-5022. 